\title{
FORTIFIKASI BUAH NAGA MERAH (Hylocereus costaricensis) PADA OPAK KASBI ( Manihot esculenta crantz)
}

\author{
Yuliana Nereroan ${ }^{1}$, Kuntjahjawati SAR., Masrukan
}

\begin{abstract}
Research has been carried out on "Fortification of red dragon fruit (Hylocereus costaricensis) in kasbi opaque (Manihot esculenta crantz)". This study aims to determine the effect of the addition of red dragon fruit pulp to opaque production on the physical, chemical properties and level of acceptance of panelists in the organoleptic test. The design used in this study was a completely randomized design (CRD) with 5 treatments and 3 replications. The data from the observations of each parameter were analyzed statistically with the F test and followed by Duncan's New Multiple Range Test (DNMRT) at the 5\% significance level. The treatment was the fortification of red dragon fruit pulp (Hylocereus costaricensis) with opaque kasbi (Manihot esculenta crantz) with opaque cassava fortification treatment by adding red dragon fruit pulp (Hylocereus costaricensis) (Control, 5\%, 15\%, 25\% and 35 The results showed that the fortification of red dragon fruit pulp (Hylocereus costaricensis) in opaque kasbi (Manihot esculenta crantz) had a significant effect on water content, ash content, starch, antioxidants, color intensity, thickness, development, color, texture, flavor and preferences. Based on the results of the organoleptic test analysis of cassava opaque which can still be accepted by the panelists, the treatment with the addition of red dragon fruit pulp is $35 \%$, namely the ratio between treatment red dragon fruit pulp (control -35\%) which has physical properties, namely the color is getting darker red. and the texture is getting brittle. While the organoleptic properties that are owned are the color getting darker red, the texture is more brittle, and the flavor is getting more red dragon fruit pulp and the taste is getting more red dragon fruit pulp.
\end{abstract}

Keyword: kasbi opaque, red dragon fruit, fortification

\begin{abstract}
ABSTRAK
Telah dilakukan penelitian tentang “Fortifikasi buah naga merah (Hylocereus costaricensis) pada opak kasbi ( Manihot esculenta crantz) ". Penelitian ini bertujuan untuk mengetahui pengaruh pada penambahan bubur buah naga merah pada pembuatan opak terhadap sifat fisik, kimia dan tingkat penerimaan panelis pada uji organoleptik. Rancangan yang digunakan pada penelitian ini adalah Rancangan Acak Lengkap (RAL) dengan 5 perlakuan dan 3 ulangan. Data hasil pengamatan dari masing-masing parameter dianalisa statistik dengan uji F dan dilanjutkan dengan uji Duncan's New Multiple Range Test (DNMRT) pada taraf signifikansi 5\%. Perlakuan yang digunakan adalah fortifikasi bubur buah naga merah (Hylocereus costaricensis) dengan opak kasbi (Manihot esculenta crantz) dengan perlakuan fortifikasi opak kasbi yaitu dengan menambahkan bubur buah naga merah (Hylocereus costaricensis) (Kontrol, 5\%,15\%,25\% dan $35 \%$. Hasil penelitian menunjukkan bahwa fortifikasi bubur buah naga merah (Hylocereus costaricensis) pada opak kasbi (Manihot esculenta crantz) berpengaruh nyata terhadap kadar air, kadar abu, pati, antioksidan, intensitas warna, ketebalan, pengembangan, warna, tekstur, flavor dan kesukaan. Berdasarkan hasil analisa uji organoleptik opak kasbi yang masih dapat diterima oleh panelis adalah pada perlakuan dengan penambahan bubur buah naga merah sebesar 35\% yaitu dengan perbandingan antara bubur buah naga merah perlakuan (kontrol -35\%) yang mempunyai sifat fisik yaitu dengan warna semakin merah kehitaman dan tekstur semakin rapuh. Sedangkan sifat organoleptik yang dimiliki yaitu dengan warna semakin merah kehitaman, tekstur semakin rapuh, dan flavor semakin terasa bubur buah naga merah dan rasanya semakin terasa bubur buah naga merah.
\end{abstract}

Kata kunci: opak kasbi, buah naga merah, fortifikasi

\section{PENDAHULUAN}

Opak merupakan makanan ciri khas daerah Maluku yang terbuat dari bahan dasarnya kasbi (Singkong) Manihot utilissima serupa kerupuk. Dalam pembuatan atau pengolahan yang sangat sederhana, dimana masih memerlukan proses pengeringan dengan penjemuran dibawah terik matahari dalam proses pengolahannya. Opak merupakan makanan khas daerah yang kurang digemari oleh masyrarakat luas terutama kalangan

\footnotetext{
${ }^{1}$ Program Studi Teknologi Pangan Fakultas Sains dan Teknologi Universitas Widya Mataram Yogyakarta

$\triangle$ yuliananereroan@gmail.com
} 
masyarakat mengingat cita rasa dari opak sendiri kurang begitu lezat dibandingkan dengan produk olahan modern. Sedangkan kerupuk terbuat dari tepung tapioka atau ketan yang diberi bumbu garam, gula, kelapa parut dan bumbu penyedap.

Keunggulan kerupuk opak dibandingkan dengan kerupuk yang lainnya adalah kerupuk yang dibuat langsung dari sehingga kadar seratnya masih tinggi. Kelemahan utama dari kerupuk opak adalah rendahnya kadar protein, sehingga nilai gizinya rendah, selain itu rasanya kurang enak. Untuk mengatasi kelemahan tersebut maka dalam pembuatan dapat ditambahkan bahan lain kaya protein agar jadi produk kerupuk yang berniali gizi yang lebih tinggi dan rasa yang lebih enak.

Dunia kuliner Indonesia berkembang dengan pesat, bermacam- macam inovasi produk terus bermuncul jaman termasuk dunia kue dan opak. Opak merupakan salah satu jenis produk yang memiliki daya tarik cukup besar di masyarakat. Opak terbuat dari umbi- umbian yaitu kasbi, salah satu penggunaan produk opak yang sedang banyak diminati saat ini adalah opak kasbi.

Sejalan dengan perkembangan dunia kuliner ini maka perlu diperkenalkan ke masyarakat berbagai buah naga dan kasbi yang dapat digunakan sebagai bahan dasar produk pangan. Misalnya serelia dan umbi -umbian yng banyak tumbuh di Indonesia seperti kasbi, ubi jalar dan lain-lainnya. Oleh karena itu tidak ada salahnya umbi- umbian diolah tidak hanya sebagai makanan sumber karbohidrat namun berkembang menjadi produk setengah jadi maupun produk jadi yang memiliki nilai tambah bagi umbi tersebut. Dalam penelitian ini penuilis akan mencoba mengaplikasikan buah naga sebagai bahan baku dalam pembuatan opak kasbi dalam bentuk bubur buah naga .

Pemilihan buah naga sebagai bahan fortifikasi opak kasbi karena buah naga yang memiliki warna merah sehingga akan mempengruhi warna akhir opak kasbi. selain itu buah naga memiliki rasa yang tidak terlalu manis sehingga sesuai dengan dengan kriteria opak berbahan dasar singkong yang tidak manis.

Kasbi adalah umbi akar dari tanaman ubi kayu, ketela pohon atau cassava. Kasbi (singkong) mudah ditanam dan dibudidayakan. Kasbi dapat ditanaman di lahan yang kurang subur dengan resiko gagal panen hanya sekitar 5\% dan tidak mudah terserang hama. Kasbi yang dipasarkan setelah dikeringkan terlebih dahulu supaya tahan disimpan agak lama dan untuk mempertahankan mutu produk serta meningkatkan nilai tambah ( Rukmana, 1997).

Opak kasbi terbuat dari singkong yang dapat dikupas terlebih dahulu, dibersihkan dan diparut dan kemudian dicetak dengan menggunakan cetakan dari aluminuim yang berbentuk lingkaran. Opak kasbi yang telah dicetak selanjutnya dikukus 3 sampai 5menit, opak kasbi yang telah dikukus siap untuk dikeringkan. Tujuan pengukusan adalah untuk menonaktifkan enzim yang akan menyebabkan perubahan warna, citarasa, tekstur dan nilai gizi yang tidak dikehendaki selama penyimpanan. Selain itu, tujuan dilakukannya pengukusan untuk mengurangi kadar air dalam bahan baku, sehingga tekstur bahan menjadi kompak (Sartika,2009).

Seiring dengan perkembangan ilmu pengetahuan dan perubahan gaya hidup masyarakat semakin kritis terhadap konsumsi makanan dan minuman untuk menunjang kesehatan, sehingga masyarakat akan lebih selektif dalam memilih suatu produk pangan. Kesibukan dan aktivitas masyarakat diera modern menunutut produsen produk pangan menciptakan sebuah inovasi produk pangan yang dapat disajikan dengan cepat dan praktis namum tetap memperhatikan kelengkapan nilai gizinya salah satu produk pangan yang saat ini banyak dikembangkan adalah produk makanan dalam bentuk opak. Makanan tersebut merupakan jenis makanan yang lebih praktis dalam bentuk kering yang telah ada dipasaran seperti opak singkong. Untuk meningkatkan manfaat dan rasa seringkali penyajian opak ditambah dengan makanan buah naga, untuk itu biar lebih praktis dan mempunyai umur simpan yang lebih lama akan dicoba membuat opak kasbi dengan penambahan bubur buah naga.

Buah naga termasuk dalam buah yang eksotis karena penampilannya yang menarik, rasanya asam manis menyegarkan dan memiliki kesehatan. Manfaat buah naga dalam penelitian ini adalah sebagai anti hiperkolestrolemik, 
sedangkan Pedreno dan Escribano (2001) menyatakan bahwa buah naga berpotensi sebagai anti radikal bebas karena mengandung betasianin.

Buah naga yang paling diminati konsumen dewasa ini adalah jenis buah naga super merah (Hylocereus costaricensis) karena bauh naga super merah memiliki rasa lebih manis tanpa rasa langu dibandingkan jenis lainnya dan diyakni lebih berkhasiat untuk kesehatan tubuh dan memiliki warna yang menarik (Anonymous, 2009).

Berdasarkan kajian awal yang sudah dilakukan terhadap opak kasbi metode penambahan bubur buah naga banyak hambatannya yang terdapat pada produk tersebut adalah memiliki rasa, warna dan teskur yang berubah pada produk awal sebelum penambahan bubur buah naga diduga banyak air dalam bubur buah naga.

\section{BAHAN DAN METODE Bahan}

Bahan baku utama yang digunakan dalam pembuatan opak kasbi (singkong) adalah kasbi (singkong) yang diperoleh di pasar Ngasem sedangkan, bahan-bahan kimia untuk analisa kimia adalah $\mathrm{H}_{2} \mathrm{SO}_{4} 1,25 \%, \mathrm{NaOH} 1 \mathrm{~N}, \mathrm{HCl}, \mathrm{H}_{3}$ $\mathrm{Bo}_{3}$, indikator phenil, indikator red metilen dan aquades.

Peralatan yang digunakan dalam penelitian ini meliputi alat untuk pembuatan opak, alat untuk analisis kimia opak. Alat-alat yang digunakan dalam pembuatan opak adalah beker gelas ukuran $1000 \mathrm{ml}$, baskom, gelas ukur ukuran $100 \mathrm{ml}$, pelat kaca berukuran $20 \times 20 \mathrm{~cm}^{2}$, cabinet dryer dan timbangan analitik. Sedangkan alat-alat yang digunakan untuk analisa kimia yaitu timbangan, botol timbang, penjepit, desikator, oven, cawan poselen, erlenmeyer $500 \mathrm{ml}$, gelas ukur, filter gelas, pengaduk batang dan kertas saring.

\section{Prosedur penelitian}

Penelitian yang dilakukan terdiri dari proses pembuatan opak kasbi (singkong) sebagai berikut:

Terlebih dahulu kasbi dikupas, pencucian setelah itu diparut tambahkan bubur buah naga aduk kembali hingga rata, setelah menjadi adonan mengukus dengan ukuran 1,5 inchi, setelah itu jemur adonan opak dalam cabinet dryer selama kurang lebih 7-8 jam, kemudian goreng opak kasbi dengan minyak panas hingga matang merata, opak kasbi siap disajikan.

\section{Analisa data}

Rancangan yang digunakan pada penelitian ini adalah Rancangan Acak Lengkap (RAL) Rancangan yang digunakan pada penelitian ini adalah Rancangan Acak Lengkap (RAL) dengan 5 perlakuan dan 3 ulangan. Data hasil pengamatan dari masing-masing parameter dianalisa statistik dengan uji F dan dilanjutkan dengan uji Duncan's New Multiple Range Test (DNMRT) pada taraf signifikansi $5 \%$.

\section{HASIL DAN PEMBAHASAN \\ Hasil Analisa Kimia Opak Kasbi (Singkong)}

Analisa kimia opak singkong yang dihasilkan penelitian ini meliputi kadar air, kadar abu, kadar pati, kadar antioksidan dan warna. Hasil analisa kimia dapat dilihat pada Gambar 1.

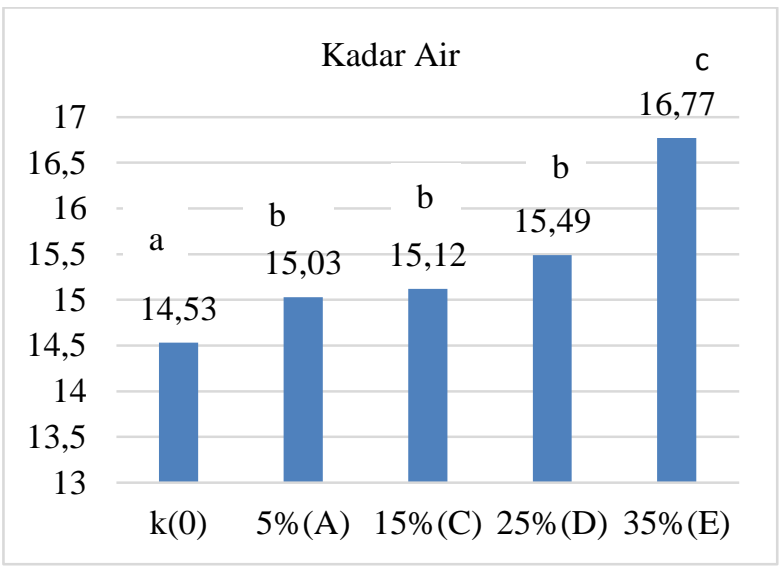

Keterangan: Rerata yang diikuti huruf yang sama menandakan antara perlakuan berbeda nyata pada taraf signifikan $5 \%$.

Gambar 1. Grafik Kadar Air Opak Kasbi

\section{Kadar air}

Kadar air sangat berpengaruh terhadap mutu dalam bahan pangan. Kadar air menunjukkan kestabilan dan index mutu bahan pangan. Kadar air suatu bahan yang dikeringkan mempengaruhi beberapa hal yaitu seberapa jauh penguapan dapat berlangsung, lamanya proses penguapan dan jalannya proses penguapan (Winarno,F,G.dkk .1980).

Berdasarkan hasil analisis sidik ragam menunjukkan bahwa pemanfaatan bubur buah 
naga merah sebagai bahan fortifikasi opak singkong antara perlakuan kontrol tanpa penambahan bubur buah naga merah dengan perlakuan penambahan bubur buah naga merah sebesar 5\% - 35\% memberikan pengaruh beda nyata pada taraf signifikansi $5 \%$ terhadap kadar air opak singkong yang dihasilkan.

Dapat dilihat pada Gambar 6 kadar air tertinggi terdapat pada perlakuan $35 \%$ dengan penambahan bubur buah naga merah yaitu sebesar 16,58. Kadar air terendah terdapat pada perlakuan kontrol tanpa penambahan bubur buah naga merah yaitu sebesar 14,53 . semakin banyak bubur buah naga merah yang ditambahkan maka semakin tinggi kadar air opak singkong yang dihasilkan.

Hasil gambar 1 menunjukkan bahwa adanya peningkatan kadar air seiring dengan meningkatnya penggunaan bubur buah naga merah mengakibatkan kadar air pada opak semakin naik. Hal ini dikarenakan oleh kandungan air pada bubur buah naga merah lebih tinggi dibandingkan dengan kadar air pada kasbi (singkong).

Kadar air merupakan karakteristik yang sangat mempengaruhi bahan pangan, karena kandungan air ini mempengaruhi penampakan, tekstur, dan citarasa makanan. Kadar air dalam bahan makanan ikut menentukan kesegaran dan daya awet bahan makanan tersebut.

\section{Kadar Abu}

Berdasarkan hasil uji lanjut DMRT taraf 5\% pada Gambar 2. Menunjukkan bahwa kadar abu jajanan opak kombinasi pati basa dengan pati kadar mineral, maka semakin rendah kadar air, menyebabkan semakin tinggi kadar abu bahan tersebut. Sehingga dengan menurunnya kadar abu suatu produk pangan dapat disebabkan karena tingginya kadar air pada produk pangan tersebut. Perlakuan penambahan bubur buah naga merah pada opak singkong memberikan pengaruh berbeda nyata terhadap kadar abu opak singkong. Hubungan penambahan bubur buah naga merah dengan kadar abu opak singkong yang dihasilkan.

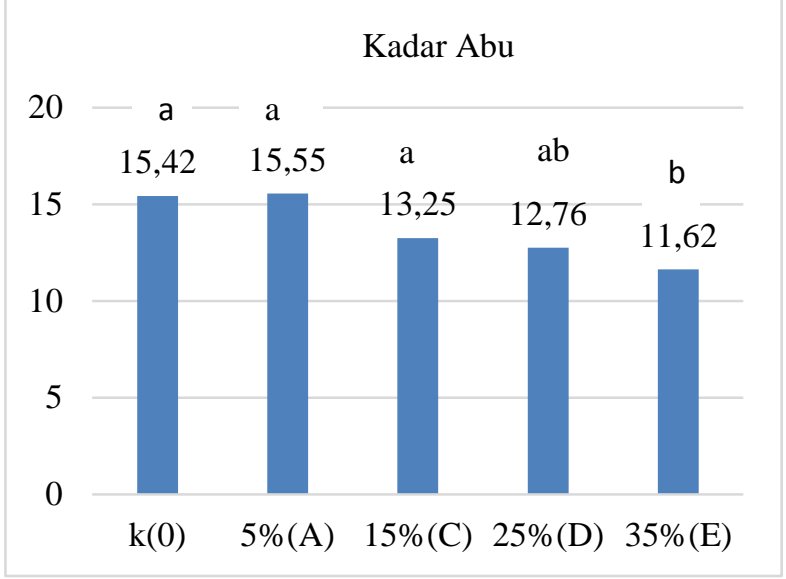

Keterangan: Rerata yang diikuti huruf yang sama menandakan antara perlakuan berbeda nyata pada taraf signifikan 5\%.

Gambar 2. Grafik Kadar Abu Opak Kasbi

Berdasarkan hasil analisis sidik ragam menunjukkan bahwa pemanfaatan bubur buah naga merah sebagai bahan fortifikasi opak singkong antara perlakuan kontrol tanpa penambahan bubur buah naga merah dengan perlakuan penambahan bubur buah naga merah sebesar 5\% - 35\% memberikan pengaruh beda nyata pada taraf signifikansi $5 \%$ terhadap kadar air opak singkong yang dihasilkan.

Grafik diatas menunjukkan kadar abu yang semakin menurun seiring dengan penambahan bubur buah naga merah yang semakin banyak. Pada setiap perlakuan kadar abu opak yang dihasilkan yang berarti penambahan memberikan pengaruh terhadap kadar abu pada opak.

Dapat dilihat pada Gambar 2 kadar abu tertinggi terdapat pada perlakuan kontrol tanpa penambahan bubur buah naga merah yaitu sebesar 15,92 Kadar abu terendah terdapat pada perlakuan dengan penambahan $35 \%$ bubur buah naga merah yaitu sebesar 11,62. semakin banyak bubur buah naga merah yang ditambahkan maka semakin menurun kadar abu opak Kasbi (singkong) yang dihasilkan.

\section{Kadar antioksidan}

Antioksidan merupakan suatu senyawa yang berperan dalam menghambat oksidasi yang diperantarai oksigen. Senyawa oksidasi memegang peranan penting dalam pertahanan tubuh terhadap penyakit. Hal tersebut disebabkan senyawa antioksidan dapat mencegah pengaruh 
buruk yang disebabkan oleh senyawa radikal bebas (Percival, 1998).

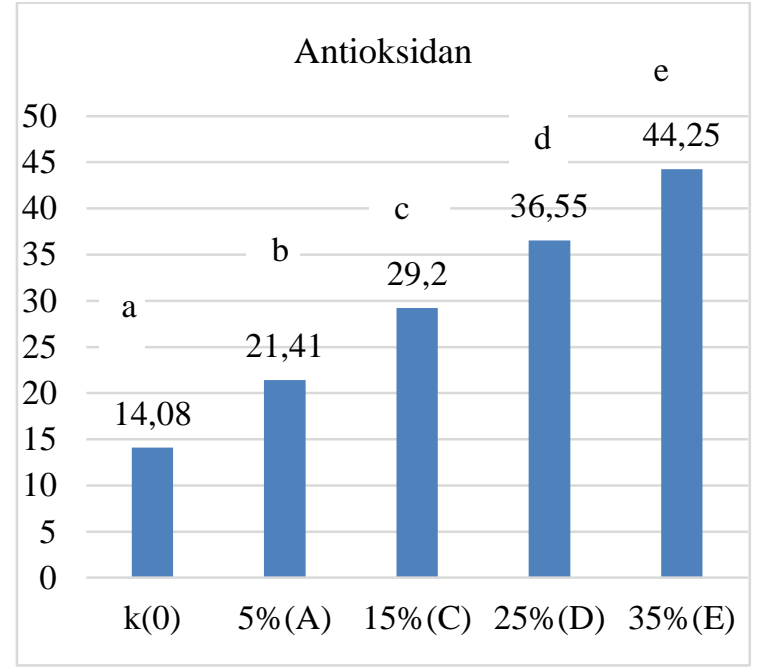

Keterangan: Rerata yang diikuti huruf yang tidak sama menandakan antara perlakuan berbeda nyata pada taraf signifikansi $5 \%$.

Gambar 3. Grafik Antioksidan Opak Kasbi

Berdasarkan hasil analisis sidik ragam menunjukkan bahwa pemanfaatan bubur buah naga merah sebagai bahan fortifikasi opak Kasbi (singkong) antara perlakuan kontrol tanpa penambahan bubur buah naga merah dengan perlakuan penambahan bubur buah naga merah sebesar 5\% - 35\% memberikan pengaruh beda nyata pada taraf signifikansi $5 \%$ terhadap kadar air opak singkong yang dihasilkan. hal ini disebabkan karena semakin banyak bubur buah naga merah ditambahkan semakin tinngi kadar antioksidan, sedangkan perlakuan pada kontrol mendapatkan kadar antiioksidan paling rendah.

\section{Kadar pati}

Pati adalah salah satu bahan penyusunan yang paling banyak dan luas terdapat dialam,sebagai karbohidrat cadangan pangan pada makanan. Sebagian besar pati disimpan dalam akar, umbi, biji buah dan umbi lapis. Simpanan cadangan tersebut berada dalam bentuk granulagranula berukuran lebih besar, disebut dengan pati cadangan.

Pati mempunyai dua komponen utama yaitu amilosa (fraksi terlarut) dan amilopektin (farksi tidak terlarut). Menurut Djatmiko dan Tahir(1985), amilopektin merupakan salah satu komponen pati yang mempengaruhi daya kembang kerupuk. Perbedaan rasio amilosa dan amilopektin dalam pati berpengaruh terhadap sifat fisik dan kimia pati. Kandungan amilopektin yang lebih tinggi akan memberikan kecenderungan pengembangan kerupuk yang lebih besar dibandingkan dengan amilosa tinggi.dapat dilihat pada Gambar Grafik 4.

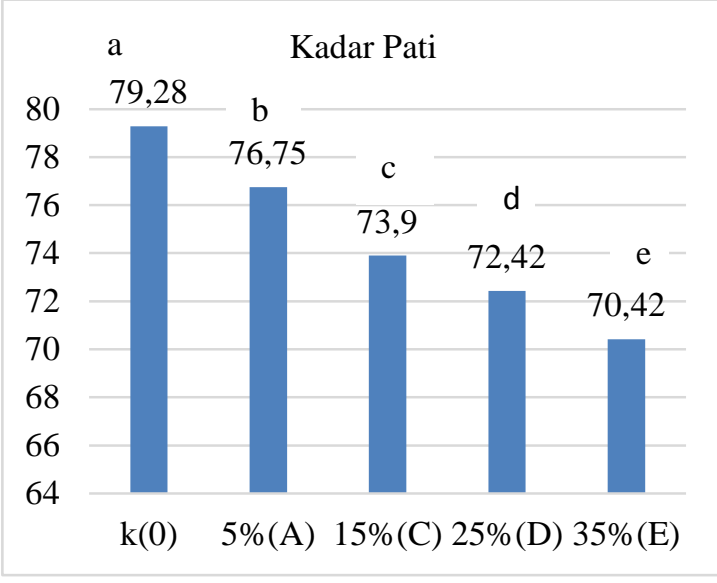

Keterangan: Rerata yang diikuti huruf yang tidak sama antara perlakuan berbeda nyata pada taraf signifikansi 5\%.

Gambar 4. Grafik Kadar Pati Opak Kasbi

Berdasarkan hasil analisis sidik ragam menunjukkan bahwa pemanfaatan bubur buah naga merah sebagai bahan fortifikasi opak singkong antara perlakuan kontrol tanpa penambahan bubur buah naga merah dengan perlakuan penambahan bubur buah naga merah sebesar 5\% - 35\% memberikan pengaruh beda nyata pada taraf signifikansi 5\% terhadap kadar air opak singkong yang dihasilkan.

Berdasarkan hasil analisis sidik ragam menunjukkan bahwa pemanfaatan bubur buah naga merah sebagai bahan fortifikasi opak singkong antara perlakuan kontrol tanpa penambahan bubur buah naga merah dengan perlakuan penambahan bubur buah naga merah sebesar 5\% - 35\% memberikan pengaruh beda nyata pada taraf signifikansi 5\% terhadap kadar air opak singkong yang dihasilkan.

\section{Warna Intensitas warna}

Warna bahan dan produk pangan dapat dibentuk oleh adanya pigmen yang secara alami terdapat dalam bahan pangan atau bahan pewarna yang ditambahkan ke dalam makanan (Andarwulan dkk., 2011). Pada pembuatan opak ini, warna merah yang dihasilkan berasal dari zat 
warna alami bubur buah naga merah yang ditambahkan.

Intensitas warna opak diukur menggunakan

Chromameter Minolta CR-400. Alat ini menggunakan sistem CIE L, a, dan b. Nilai L, a, $\mathrm{b}$, diubah dari sistem koordinat persegi menjadi sistem koordinat silinder. Nilai L menyatakan parameter Light mempunyai nilai $0 \mathrm{k}$ warna hitam antara 0 sampai 100 warna putih, nilai L menyatakan kecahayaan pantul yang menghasilkan warna kromatik putih abu-abu dan hitam, a menunjukkan warna kromatik campuran merah hijau, nilai +a antara 0 sampai +100 dan warna merah antara 0 sampai $-80, \mathrm{~b}$ menunjukkan warna kromatik campuran biru kuning, nilai $+b$ antara 0 sampai +70 dan warna kuning, -b antara 0 sampai -70 untuk warna biru.

Berdasarkan hasil analisis sidik ragam menunjukkan bahwa pemanfaatan bubur biah naga merah sebagai bahan fortifikasi bubur buah naga merah memberikan pengaruh berbeda nyata pada taraf signifikansi 5\% terhadap nilai opak yang dihasilkan. Hasil analisis intensitas warna opak dapat dilihat pada Tabel 1.

Tabel 1. Tabel Warna Opak Kasbi

\begin{tabular}{ccccc}
\hline Perlakuan & \multicolumn{4}{c}{ Warna } \\
\cline { 2 - 5 } & $\mathbf{L}$ & $\mathbf{a}$ & $\mathbf{b}$ & $\mathbf{\Delta E}$ \\
\hline Kontrol & $58,53(\mathrm{e})$ & $3,01(\mathrm{a})$ & $0,40(\mathrm{a})$ & $59,51(\mathrm{a})$ \\
Buah naga & $39,97(\mathrm{~d})$ & $10,48(\mathrm{a}$ b) & $0,69(\mathrm{~b})$ & $41,72(\mathrm{a})$ \\
$\quad 5 \%$ & & & & \\
Buah naga & $31,19(\mathrm{c})$ & $18,39(\mathrm{bc})$ & $1,39(\mathrm{c})$ & $36,24(\mathrm{a})$ \\
$\quad 15 \%$ \\
$\begin{array}{c}\text { Buah naga } \\
\text { 25\% }\end{array}$ & $29,12(\mathrm{~b})$ & $22,88(\mathrm{c})$ & $2,43(\mathrm{~d})$ & $34,47(\mathrm{~b})$ \\
Buah naga & $28,10(\mathrm{a})$ & $25,54(\mathrm{c})$ & $10,35(\mathrm{e})$ & $37,98(\mathrm{c})$ \\
$35 \%$ & & & &
\end{tabular}

Keterangan : L* adalah Lightness antara 0 sampai 100 adalah warna putih

$a^{*}$ adalah warna merah antara 0 sampai 80 dan warna hijau antara 0 sampai -100

b* adalah warna kuning antara 0 antara 70 dan warna biru antara 0 sampai -70

Berdasarkan Tabel 1 dapat dilihat hasil analisis intensitas warna opak dengan pemanfaatan bubur buah naga merah sebagai bahan fortifikasi opak diperoleh nilai $\mathrm{L}^{*}$ memiliki kisaran 58,53-28,10 yang menunjukan warna putih abu-abu semakin kehitaman, nilai a* berkisar antara 3,01 yang menunjukan warna merah hijau dan antara 10,48-25,54 menunjukan warna makin merah hijau gelap, nilai $b^{*}$ berkisar antara 0,40-10,35 menunjukkan warna kuning semakin gelap dan nilai $\Delta \mathrm{E}$ berkisaran antara 59,51-37,98 menunjukan kecerahan warna terang semakin gelap.

Pengujian intensitas warna dilakukan menggunakan alat colormeter hunter. Sistem notasi warna hunter dicirikan dengan 3 parameter warna yaitu warna kromatik $\left(\mathrm{a}^{*}\right)$ menyatakan warna kromatik campuran merahhijau dengan nilai $+a^{*}$ dari 0 sampai +100 untuk warna merah dan $-\mathrm{a}^{*}$ dari 0 sampai -80 untuk warna merah hijau, intensitas warna $\left(b^{*}\right)$ menyatakan warna kromatik campuran birukuning dengan nilai $+\mathrm{b}^{*}$ dari 0 sampai +70 untuk warna kuning dan $-\mathrm{b}^{*}$ dari 0 sampai -70 untuk warna biru dan tingkat kecerahan ( $\left.\mathrm{L}^{*}\right)$ (Andarwulan dkk., 2011). Sedangkan nilai hue menyatakan kecerahan produk sesungguhnya (Hasanah, 2007).

Tabel 1 menunjukkan semakin banyak penambahan bubur buah naga menyebabkan nilai warna opak yang dihasilkan semakin merah gelap. Warna merah opak hasil penelitian ini yang berasal dari kandungan klorofil pada bubur buah naga.

\section{Kesukaan}

Penerimaan kesukaan merupakan penerimaan panelis secara keseluruhan terhadap beberapa parameter yaitu warna, tekstur, dan flavor dari opak singkong.

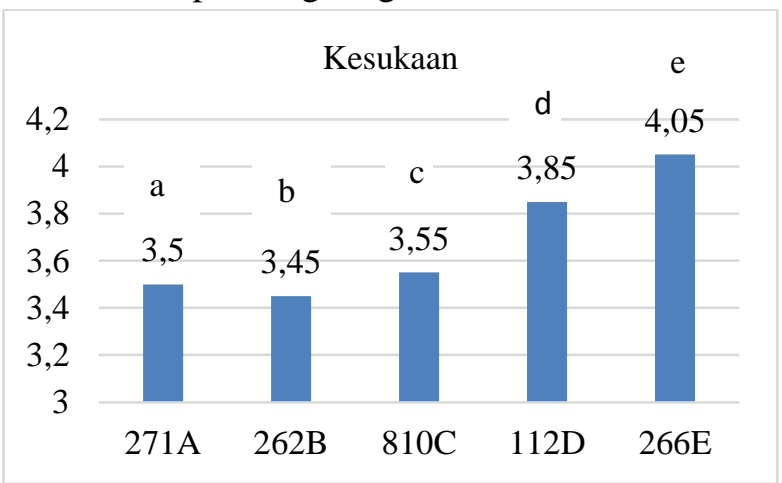

Gambar 5. Grafik Kesukaan Opak Kasbi

Berdasarkan Gambar 5 menunjukkan bahwa antara perlakuan kontrol tanpa penambahan bubur buah naga merah dengan perlakuan penambahan bubur buah naga merah $5 \%-35 \%$ memberikan pengaruh beda nyata 
terhadap nilai kesukaan opak singkong yang dihasilkan.

Pada Gambar 5. hasil kesukaan secara keseluruhan yang masih dapat diterima oleh panelis adalah opak singkong pada perlakuan dengan penambahan bubur buah naga merah yaitu sebanyak 5\% - 35\%. Hal ini disebabkan karena dengan semakin banyaknya penambahan bubur buah naga merah diatas $25 \%$, maka opak yang dihasilkan akan mempunyai warna yang semakin gelap/kehitaman dengan tekstur semakin rapuh, dan flavor bubur buah naga semakin terasa langu.

\section{KESIMPULAN}

Berdasarkan hasil penelitian analisa kimia, fisik, dan organoleptik penelitian yang telah dilakukan terhadap opak kasbi dengan pemanfaatan bubur buah naga merah (Hylocereus Costaricensis) sebagai bahan fortiikasi opak kasbi (Manihot Crantz) didapatkan kesimpulan bahwa hasil analisa uji organoleptik opak kasbi yang masih dapat diterima oleh panelis adalah pada perlakuan dengan penambahan bubur buah naga merah sebesar $35 \%$ yaitu dengan perbandingan antara bubur buah naga merah perlakuan (kontrol $-35 \%$ ) yang mempunyai sifat fisik yaitu dengan ketebalan terdapat pada perlakuan kontrol sebesar 0,43 dan pengembangan terdapat pada perlakuan kontrol sebesar 60,52. Sedangkan sifat kimia dengan kadar air 35\% sebesar 16,78, kadar abu $35 \%$ sebesar 11,62, antioksidan $35 \%$ sebesar 44,26, kadar pati kontrol sebesar 79,28 dan intensitas warna L memiliki kisaran 58,53-28,10 yang menunjukan warna putih abu-abu semakin kehitaman menunjukan warna $\mathrm{a}^{*}$ berkisaran antara 3,01 menunjukan warna hijau antara 10,4825,54 menunjukan warna semakin merah hijau gelap dan nilai $\mathrm{b}^{*}$ berkisaran antara 0,40-10,35 menunjukan warna kuning gelap sedangkan nilai $\Delta \mathrm{E}$ berkisaran antara 59,51-37,98 menujukan warna terang semakin gelap. Sedangkan sifat organoleptik yang dimiliki yaitu dengan warna semakin merah terdapat pada perlakuan 35\% sebesar 5 merah gelap kehitaman, tekstur semakin rapuh $35 \%$ sebesar 3,15, flavor $35 \%$ sebesar 3,2 semakin terasa bubur buh naga merah dan kesukaan 35\% sebesar 4,05 yang mempunyai warna merah gelap atau kehitaman.
Penambahan bubur buah naga merah dalam pembuatan memberikan pengaruh terhadap sifat fisik, kimia dan organoleptik dengan peningkatan ketebalan, pengembangan, pati, kadar abu dan antioksidan sedangkan penurunan terhadap warna, serta juga berpengaruh terhadap warna, flavor, tekstur dan tingkat kesukaan opak kasbi yang dihasilkan.

\section{DAFTAR PUSTAKA}

Andarwulan, N., Kusnandar, F, dan Herawati, D. 2011. Analisis Pangan. PT. Dian Rakyat. Jakarta.

Anonymous. 2009. Turunkan Kolestrol dengan Buah Naga

Cahyono, B. (2009). Sukses Bertanam Buah Naga. Jakarta: Pustaka Mina.

Escribano, J., Pedreño, M.A.,Garcia-Carmona, F. \& Muñoz,R. 1998. Characterization of the Antiradical Activity of Betalains from Beta Vulgaris L. Roots. Phytochemical Analysis 9: 124-127.

Hasanah, I. 2007. Bercocok Tanam Padi. Azka Mulia Media. Jakarta. 68 hal.

Koswara, S. 2009. Pengolahan Aneka Kerupuk. Ebookpangan. Com.

Rukmana .1997. Ubi Kayu, Budidaya dan Pasca Panen. Penerbit Kanisius. Yogyakarta.

Sartika, R. A. D. 2009. Pengaruh Suhu dan Lama ProsesMengukus Terhadap Pembentukan Asam Lemak Trans. Makaira Sains I: 23-28.

Winarno, FG. 1980. Pengantar Teknologi Pangan. PT. Gramedia. Jakarta. 